\title{
Versatile three-component procedure for combinatorial synthesis of spiro-oxindoles with fused chromenes catalysed by L-proline
}

\author{
MAJID M HERAVI ${ }^{\mathrm{a}, *}$, MASOUMEH ZAKERI ${ }^{\mathrm{b}, *}$ and AREZOO MOHARAMI ${ }^{\mathrm{a}}$ \\ ${ }^{a}$ Department of Chemistry, School of Sciences, Alzahra University, Vanak, Tehran 1993893973, Iran \\ bYoung Researchers Club, Tehran North Branch, Islamic Azad University, Tehran 1913674711, Iran \\ e-mail: mmh1331@yahoo.com; ms.zakeri@gmail.com
}

MS received 30 October 2011; revised 15 February 2012; accepted 10 April 2012

\begin{abstract}
An efficient synthesis of spiro-oxindoles is accomplished by a one-pot three-component condensation of isatin, malononitrile or cyanoacetic ester and naphthol in the presence of L-proline as a catalyst. This method is of great value because of its shorter reaction times, high yield, and easy processing.
\end{abstract}

Keywords. Spiro-oxindoles; naphthol; L-proline; isatin.

\section{Introduction}

Oxindole compounds are known to possess a variety of biological activities, such as potent inhibition of monoamine oxidase in human urine and rat tissues, ${ }^{1}$ inhibition of several enzymes such as acetylcholinestrease, ${ }^{2}$ and potent antagonist of in vitro receptor binding by atrial natriuretic peptide. ${ }^{3}$ Furthermore, some of oxindoles, spiro-annulated with heterocycles in the 3position, highly enhances biological activity. ${ }^{4,5}$ Among the heterocyclic spiro-oxindole ring system, functionally substituted $4 H$-chromenes have received considerable attention due to their wide range of useful biological properties, which include antiviral, ${ }^{6}$ herbicidal, ${ }^{7}$ anticonvulsant and analgesic, ${ }^{8}$ antitumor, ${ }^{9}$ and central nervous system activities. ${ }^{10}$

In recent years, several methods for the synthesis of spiro-oxindoles with fused $4 H$-chromenes via multicomponent condensation reactions have been reported. The conventional synthesis involves a three-component condensation of isatin (or aromatic aldehyde) and malononitrile with dimedone or barbituric acid or 4hydroxycoumarin. Synthesis of spiro-chromene derivatives have been catalysed by phase-transfer catalysts such as tetrabutylammonium fluoride, ${ }^{11}$ triethylbenzylammonium chloride (TEBA), ${ }^{12}$ and sodium stearate, ${ }^{13}$ as well as basic catalysts such as alum ${ }^{14}$ and ethylenediamine diacetate. ${ }^{15}$ However, to the best of our knowledge, there is only one report about the synthesis of spiro-chromene derivatives using isatin and malononi-

*For correspondence trile with naphthol as starting materials. ${ }^{16}$ In that paper, Shanthi et al. reported the synthesis of $4 H$-chromene derivatives by hazardous $\mathrm{InCl}_{3}$ catalyst at reflux in acetonitrile for $1.5 \mathrm{~h}$. Therefore, there is still a demand for simple and facile methodologies for the preparation of spiro-chromene compounds with more efficiency and shorter reaction times.

L-proline is an amino acid that is used in many pharmaceutical, biotechnological applications. This small organic molecule and its derivatives are often used as asymmetric catalyst in organic reactions and they are readily commercially available. L-Proline has been used in catalysed aldol condensation, ${ }^{17}$ Mannich, ${ }^{18}$ Michael, ${ }^{19}$ Diels-Alder ${ }^{20}$ and Biginelli reactions. ${ }^{21}$ More recently, L-proline and its derivatives have been used in multicomponent reactions. ${ }^{22}$

Due to the biological activity of $4 H$-chromenes containing 2-oxindole nucleus, we investigated a simple and efficient method for the synthesis of spiro-oxindoles with fused chromenes, through the three-component reaction of isatin derivatives, malononitrile or cyanoacetic ester, and $\alpha$-naphthol $/ \beta$-naphthol compounds using L-proline as the catalyst (scheme 1).

\section{Experimental}

\subsection{General remarks}

Products were characterized by M.P., IR, ${ }^{1} \mathrm{H}$ NMR, and ${ }^{13} \mathrm{C}$ NMR. Melting points were measured by using the capillary tube method with an electro thermal 9200 apparatus. ${ }^{1} \mathrm{H}$ NMR and ${ }^{13} \mathrm{C}$ NMR spectra were recorded on a Bruker AQS AVANCE-500 MHz and 

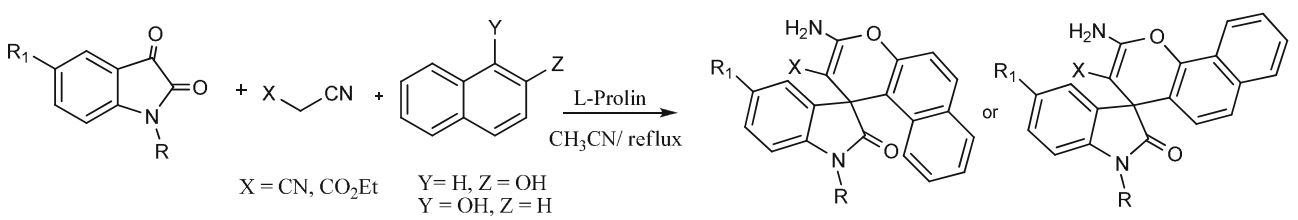

Scheme 1. One-pot synthesis of spiro-oxindole catalysed by L-proline.
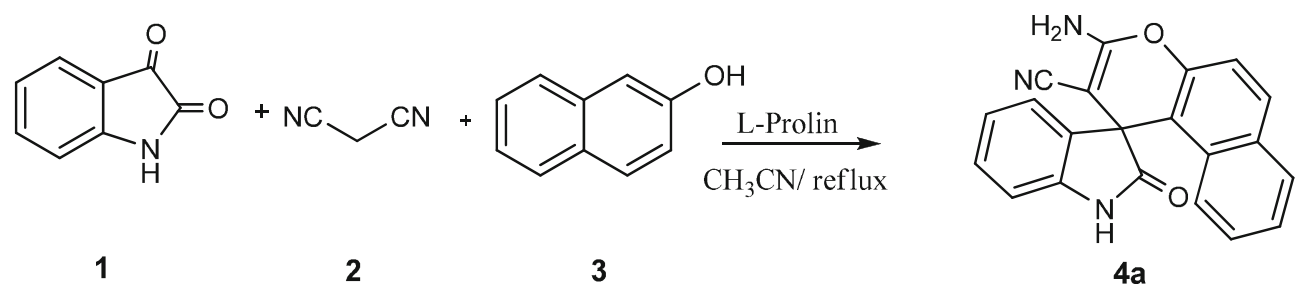

Scheme 2. Model reaction for the synthesis of $\mathbf{4 a}$.

$125 \mathrm{MHz}$ spectrometer using TMS as an internal standard $\left(\mathrm{CDCl}_{3}\right.$ solution). IR spectra were recorded from $\mathrm{KBr}$ disk on the FT-IR Bruker Tensor 27.

\subsection{General procedure for the synthesis of spiro-oxindoles with fused $4 \mathrm{H}$-chromenes}

To the reaction mixture containing isatin $(1 \mathrm{mmol})$, malononitrile $(1 \mathrm{mmol})$, and $\beta$-naphthol $(1 \mathrm{mmol})$ in acetonitrile $(10 \mathrm{~mL})$, L-proline $(5 \mathrm{~mol} \%)$ was added and stirred at reflux for about $30 \mathrm{~min}$. After completion, monitored by TLC ( $n$-hexane/ethyl acetate: 7/3), the reaction mixture was diluted with water and the precipitate formed was filtered, dried, and purified by column chromatography to afford the pure product in $90 \%$ yield. This procedure was followed for the synthesis of all the spiro-oxindoles.

The physical and spectral data of the some products are given below.

\section{2a 3-Amino-2'-oxospiro[benzo[ $f$ ]chromene-1,3'-} indoline]-2-carbonitrile (4a): IR (KBr): 3310, 3250, 3184, 2195, 1655, $1154 \mathrm{~cm}^{-1}$; ${ }^{1} \mathrm{H}$ NMR (DMSO-d 6 , $500 \mathrm{MHz}): \delta 6.57(1 \mathrm{H}, \mathrm{d}, \mathrm{J}=8.1 \mathrm{~Hz}, \mathrm{ArH}), 6.98-7.02$ $(2 \mathrm{H}, \mathrm{m}, \mathrm{ArH}), 7.08(1 \mathrm{H}, \mathrm{d}, \mathrm{J}=7.3 \mathrm{~Hz}, \mathrm{ArH}), 7.29(1 \mathrm{H}$, $\mathrm{t}, \mathrm{J}=7.6 \mathrm{~Hz}, \mathrm{ArH}), 7.44\left(2 \mathrm{H}, \mathrm{s}, \mathrm{NH}_{2}\right), 7.53(1 \mathrm{H}, \mathrm{d}, \mathrm{J}=$ $8.1 \mathrm{~Hz}, \operatorname{ArH}), 7.61(1 \mathrm{H}, \mathrm{t}, \mathrm{J}=7.3 \mathrm{~Hz}, \mathrm{ArH}), 7.67(1 \mathrm{H}$, $\mathrm{t}, \mathrm{J}=7.3 \mathrm{~Hz}, \operatorname{ArH}), 7.89(1 \mathrm{H}, \mathrm{d}, \mathrm{J}=8.1 \mathrm{~Hz}, \operatorname{ArH})$, $8.28(1 \mathrm{H}, \mathrm{d}, \mathrm{J}=8.6 \mathrm{~Hz}, \mathrm{ArH}), 10.68(1 \mathrm{H}, \mathrm{s}, \mathrm{NH}) \mathrm{ppm}$; ${ }^{13} \mathrm{C}$ NMR (DMSO-d $6,125 \mathrm{MHz}$ ): $\delta$ 51.5, 58.9, 111.0, $111.7,117.3,118.9,123.0,124.1,124.8,125.3,127.2$,
Table 1. Synthesis of spiro-oxindole $\mathbf{4 a}$ using different catalyst. $^{\mathrm{a}}$

\begin{tabular}{lcc}
\hline Catalyst & $\begin{array}{r}\text { Time } \\
(\mathrm{min})\end{array}$ & $\begin{array}{c}\text { Yield }^{\mathrm{b}} \\
(\%)\end{array}$ \\
\hline- & 180 & 15 \\
Nano Zn(bpdo $)_{2} .2 \mathrm{H}_{2} \mathrm{O} / \mathrm{MCM}-41(0.05 \mathrm{~g})$ & 180 & 50 \\
Nano Pd/SBA-15 $(0.05 \mathrm{~g})$ & 260 & 55 \\
$\mathrm{Cr}_{2} \mathrm{O}_{3} / \mathrm{SBA}-15(0.05 \mathrm{~g})$ & 105 & 80 \\
$\mathrm{DABCO}(10 \mathrm{~mol} \%)$ & 90 & 70 \\
L-Proline $(5 \mathrm{~mol} \%)$ & 30 & 90
\end{tabular}

${ }^{\mathrm{a}}$ The reaction was carried out with isatin, malononitrile, and $\beta$-naphthol.

${ }^{\mathrm{b}}$ Isolated yields

Table 2. Solvent effects on the synthesis of compound $\mathbf{4 a}$. $^{\mathrm{a}}$

\begin{tabular}{lcc}
\hline Solvent & Time (min) & Yield $^{\mathrm{b}}(\%)$ \\
\hline $\mathrm{CH}_{3} \mathrm{CN}$ (reflux) & 30 & 90 \\
$\mathrm{CHCl}_{3}$ (reflux) & 50 & 70 \\
EtOH (reflux) & 50 & 90 \\
Solvent-free & 85 & 75
\end{tabular}

${ }^{\mathrm{a}}$ The reaction was carried out with isatin, malononitrile, and $\beta$-naphthol.

${ }^{\mathrm{b}}$ Isolated yields 
Table 3. Synthesis of spiro-oxindoles with fused chromenes catalysed by L-proline.

\begin{tabular}{|c|c|c|c|c|c|c|c|c|c|c|}
\hline & & & $\mathrm{CN}, \mathrm{CO}_{2} \mathrm{Et}$ & & $\begin{array}{l}\mathrm{Z}= \\
\mathrm{H}, \mathrm{Z}\end{array}$ & & $\begin{array}{l}\mathrm{l} \\
\mathrm{R}\end{array}$ & & $\begin{array}{l}i \\
R\end{array}$ & \\
\hline Compound & $\mathrm{R}$ & $\mathrm{R}_{1}$ & $X$ & Y & Z & Products & $\begin{array}{l}\text { Time } \\
(\mathrm{min})\end{array}$ & $\begin{array}{c}\mathrm{Mp}\left({ }^{\circ} \mathrm{C}\right) \\
\text { found }\end{array}$ & $\begin{array}{c}\operatorname{Mp}\left({ }^{\circ} \mathrm{C}\right) \\
\text { Lit. }{ }^{16}\end{array}$ & $\begin{array}{c}\text { Yield }^{\mathrm{a}} \\
(\%)\end{array}$ \\
\hline $4 a$ & $\mathrm{H}$ & $\mathrm{H}$ & $\mathrm{CN}$ & $\mathrm{H}$ & $\mathrm{OH}$ & & 30 & $240-242$ & 236 & 90 \\
\hline $4 b$ & $\mathrm{Me}$ & $\mathrm{H}$ & $\mathrm{CN}$ & $\mathrm{H}$ & $\mathrm{OH}$ & & 30 & $267-269$ & 266 & 85 \\
\hline $4 c$ & $\mathrm{H}$ & $\mathrm{Cl}$ & $\mathrm{CN}$ & $\mathrm{H}$ & $\mathrm{OH}$ & & 35 & $>300$ & - & 80 \\
\hline $4 d$ & $\mathrm{H}$ & $\mathrm{Br}$ & $\mathrm{CN}$ & $\mathrm{H}$ & $\mathrm{OH}$ & & 40 & $>300$ & - & 83 \\
\hline $4 e$ & $\mathrm{H}$ & $\mathrm{H}$ & $\mathrm{CN}$ & $\mathrm{OH}$ & $\mathrm{H}$ & & 45 & 222 & 222 & 85 \\
\hline $4 f$ & $\mathrm{H}$ & $\mathrm{H}$ & $\mathrm{CO}_{2} \mathrm{Et}$ & $\mathrm{H}$ & $\mathrm{OH}$ & & 45 & $262-264$ & - & 75 \\
\hline $4 g$ & $\mathrm{Me}$ & $\mathrm{H}$ & $\mathrm{CO}_{2} \mathrm{Et}$ & $\mathrm{H}$ & $\mathrm{OH}$ & & 40 & $258-260$ & 266 & 81 \\
\hline $4 h$ & $\mathrm{H}$ & $\mathrm{H}$ & $\mathrm{CO}_{2} \mathrm{Et}$ & $\mathrm{OH}$ & $\mathrm{H}$ & & 55 & $229-231$ & 229 & 80 \\
\hline
\end{tabular}

${ }^{\mathrm{a}}$ The yields refer to isolated products

129.6, 129.9, 130.5, 131.4, 131.8, 135.9, 141.7, 148.5, 2.2b 3-Amino-l'-methyl-2'-oxospiro[benzo[ $f$ ]chromene160.1, 179.5 ppm; Anal.Calcd for $\mathrm{C}_{21} \mathrm{H}_{13} \mathrm{~N}_{3} \mathrm{O}_{2}(\%)$ : C, 1,3'-indoline]-2-carbonitrile (4b): $\mathrm{IR}(\mathrm{KBr}): 3315,3225$, 74.33; H, 3.86; N, 12.38. Found: C, 74.26; H, 3.92; N, 3186, 2194, 1656, $1199 \mathrm{~cm}^{-1}$; ${ }^{1} \mathrm{H}$ NMR (DMSO12.30 . $\left.\mathrm{d}_{6}, 500 \mathrm{MHz}\right): \delta 3.25\left(3 \mathrm{H}, \mathrm{s}, \mathrm{CH}_{3}\right), 6.54(1 \mathrm{H}, \mathrm{d}$, 

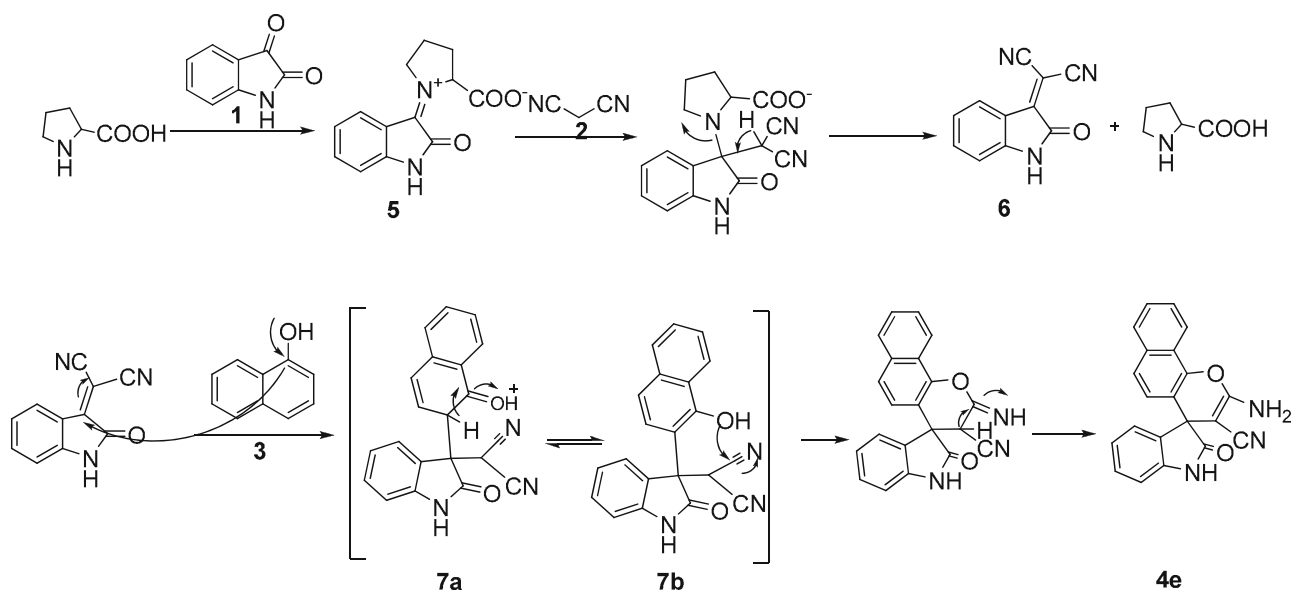

Scheme 3. Investigation of a possible reaction mechanism.

$\mathrm{J}=8.1 \mathrm{~Hz}, \operatorname{ArH}), 6.88-7.01(2 \mathrm{H}, \mathrm{m}, \operatorname{ArH}), 7.06$ $(1 \mathrm{H}, \mathrm{d}, \mathrm{J}=7.5 \mathrm{~Hz}, \mathrm{ArH}), 7.29(1 \mathrm{H}, \mathrm{t}, \mathrm{J}=7.6 \mathrm{~Hz}$, ArH), $7.40\left(2 \mathrm{H}, \mathrm{s}, \mathrm{NH}_{2}\right), 7.57(1 \mathrm{H}, \mathrm{d}, \mathrm{J}=8.1 \mathrm{~Hz}$, ArH), 7.60-7.66 (2H, m, ArH), $7.89(1 \mathrm{H}, \mathrm{d}, \mathrm{J}=8.1 \mathrm{~Hz}$, ArH), $8.28(1 \mathrm{H}, \mathrm{d}, \mathrm{J}=8.2 \mathrm{~Hz}, \mathrm{ArH}) \mathrm{ppm} ;{ }^{13} \mathrm{C} \mathrm{NMR}$ (DMSO-d ${ }_{6}, 125 \mathrm{MHz}$ ): $\delta 26.9,51.3,57.6,110.9,111.7$, $117.5,118.3,123.2,124.1,124.9,125.3,125.9,129.6$, $129.9,130.8,131.1,131.8,135.9,141.8,148.5,160.5$, 178.9 ppm; Anal.Calcd for $\mathrm{C}_{22} \mathrm{H}_{15} \mathrm{~N}_{3} \mathrm{O}_{2}(\%)$ : C, 74.78; H, 4.28; N, 11.89. Found: C, 74.70; H, 4.35; N, 11.84 .

2.2c Ethyl 3-amino-2'-oxospiro[benzo[f ]chromene1,3'-indoline]-2-carboxylate (4f): IR (KBr): 3456, $3330,3155,1703,1670,1159 \mathrm{~cm}^{-1} ;{ }^{1} \mathrm{H}$ NMR (DMSO$\left.\mathrm{d}_{6}, 500 \mathrm{MHz}\right): \delta 1.90\left(3 \mathrm{H}, \mathrm{t}, \mathrm{J}=7.0 \mathrm{~Hz}, \mathrm{CH}_{3}\right), 3.65-$ $3.68\left(2 \mathrm{H}, \mathrm{m}, \mathrm{CH}_{2}\right), 6.48(1 \mathrm{H}, \mathrm{d}, \mathrm{J}=7.5 \mathrm{~Hz}, \mathrm{ArH}), 7.04$ $7.10(2 \mathrm{H}, \mathrm{m}, \mathrm{ArH}), 7.18(1 \mathrm{H}, \mathrm{d}, \mathrm{J}=7.5 \mathrm{~Hz}, \mathrm{ArH}), 7.37$ $(1 \mathrm{H}, \mathrm{t}, \mathrm{J}=8.1 \mathrm{~Hz}, \mathrm{ArH}), 7.47\left(2 \mathrm{H}, \mathrm{s}, \mathrm{NH}_{2}\right), 7.53(1 \mathrm{H}$, $\mathrm{d}, \mathrm{J}=8.5 \mathrm{~Hz}, \operatorname{ArH}), 7.59(1 \mathrm{H}, \mathrm{t}, \mathrm{J}=8.1 \mathrm{~Hz}, \operatorname{ArH})$, $7.65(1 \mathrm{H}, \mathrm{t}, \mathrm{J}=8.0 \mathrm{~Hz}, \operatorname{ArH}), 7.86(1 \mathrm{H}, \mathrm{d}, \mathrm{J}=8.5 \mathrm{~Hz}$, $\operatorname{ArH}), 7.28(1 \mathrm{H}, \mathrm{d}, \mathrm{J}=8.6 \mathrm{~Hz}, \operatorname{ArH}), 10.77(1 \mathrm{H}, \mathrm{s}, \mathrm{NH})$ ppm; ${ }^{13} \mathrm{C}$ NMR (DMSO-d 6 , $\left.125 \mathrm{MHz}\right): \delta 13.2,51.3$, 55.6, 67.6, 109.8, 115.2, 118.9, 121.3, 123.3, 123.8, $124.0,125.0,125.2,127.5,128.2,129.7,133.8,134.0$, 143.5, 144.6, 161.6, 168.5, 178.6 ppm. Anal.Calcdfor $\mathrm{C}_{23} \mathrm{H}_{18} \mathrm{~N}_{2} \mathrm{O}_{4}(\%)$ : C, 71.49; H, 4.70; N, 7.25. Found: C, 71.43; H, 4.62; N, 7.11.

Characterized data details for other compounds have been provided as supporting information.

\section{Results and discussion}

In our initial study, evaluation of various additives was carried out for the synthesis of spiro-oxindole derivatives in acetonitrile medium. After some preliminary experiments, it was found that a mixture of isatin $\mathbf{1}$, malononitrile 2, and $\beta$-naphthol $\mathbf{3}$ in acetonitrile in the presence of a catalytic amount of L-proline could afford 2-amino $\quad$ spiro[ $[(4 H)$-benzo $(f)$ chromen-4,3'-(3'H)indol]-( $\left(1^{\prime} H\right)-2^{\prime}$-one-3-carbonitrile $\mathbf{4 a}$ in excellent yield (scheme 2). The procedure was simple and easy to operate.

We examined this reaction in the absence and presence of several additives. The results are summarized in table 1. It was found that when the reaction was carried out without any additives, only trace product was detected (table 1, entry 1). Immobilized $\mathrm{Zn}$ (II) complex with oxygen donor ligand $\left(2,2^{\prime}\right.$ bipyridine $1,1^{\prime}$ dioxide (bpdo)) within nanoreactors of MCM-41 [nano $\mathrm{Zn}$ (bpdo) $)_{2} .2 \mathrm{H}_{2} \mathrm{O} / \mathrm{MCM}-41$ ], nano $\mathrm{Pd} / \mathrm{SBA}-15$, $\mathrm{Cr}_{2} \mathrm{O}_{3} / \mathrm{SBA}-15$ and DABCO catalysts were examined in the present study. As shown in table 1, these catalysts afforded the desired product but only in moderate yields (table 1, entries 2, 3, 4 and 5). The best result was obtained when L-proline was used as seen in the yield and the reaction time (table 1 , entry 6). So L-proline was chosen as the catalyst for this reaction.

Choosing an appropriate solvent is of crucial importance for the successful synthesis. To search for the optimal solvent, reaction of isatin, malononitrile, and $\beta$ naphthol was examined using acetonitrile, chloroform and ethanol at reflux, respectively and solvent-free conditions. As shown in table 2, the reaction using acetonitrile as the solvent resulted in higher yields and shorter reaction time. So, acetonitrile was used as the solvent for further optimization of reaction conditions.

To explore the scope and versatility of this method, various similar reactions were investigated using different isatin with malononitrile or cyanoacetic ester and $\alpha$-naphthol $/ \beta$-naphthol yielding different $4 H$-benzo[ $f]$ 
chromene $\mathbf{4 a - h}$ (table 3 ). The structures of compounds were confirmed by spectroscopic methods. (see experimental)

The formation of spiro-oxindole $\mathbf{4 e}$ can be explained by Knoevenagel condensation and Michael addition followed by cyclization, as shown in scheme 3. The process represents a typical cascade reaction in which the isatin $\mathbf{1}$ condenses with malononitrile $\mathbf{2}$ to afford isatylidene malononitrile derivative $\mathbf{6}$ in the presence of L-proline. First, L-proline catalyses the formation of iminium ion $\mathbf{5}$ in reaction with isatin $\mathbf{1}$. Then, after the condensation malononitrile $\mathbf{2}$ and isatin $\mathbf{1}$ produce intermediate $\mathbf{6}$ and after the elimination of L-proline, 6 is attacked via Michael addition of $\alpha$-naphthol 3 to give the intermediate 7 followed by the cycloaddition of hydroxyl group to the cyano moiety to form the desired product 4e.

It is to be noted that the products obtained are racemic. Therefore, we can conclude that L-proline plays a key role in this reaction and catalyses only the formation of intermediate $\mathbf{6}$ and does not take part in the generation of spiranic stereocenter. Hence, stereoselection is not achieved.

\section{Conclusion}

In conclusion, we have developed a quick, clean, and simple method for the synthesis of spiro-oxindoles derivatives with fused $4 H$-chromenes catalysed by L-proline. In comparison with the recently reported method for preparation of $4 \mathrm{H}$-chromene derivatives our method gives a straightforward procedure with reduced reaction time and mild reaction conditions.

\section{Supporting information}

The electronic supporting information can be seen in www.ias.ac.in/chemsci.

\section{References}

1. Glover V, Halket J M, Watkins P J, Clow A, Goodwin B L and Sandler M J 1998 Neurochem. 51656

2. Kumar R, Bansal R C and Mahmood A 1993 Biog. Amines 9281

3. Medvedev A E, Clow A, Sandler M and Glover V 1996 Biochem. Pharmacol. 52385

4. Da Silva J F M, Garden S J and Pinto A C 2001 J. Braz. Chem. Soc. 12273

5. Abdel-Rahman A H, Keshk E M, Hanna M A and El-Bady Sh M 2004 Bioorg. Med. Chem. 122483

6. Hiramoto K, Nasuhara A, Michiloshi K, Kato T and Kikugawa K 1997 Mutat. Res. 39547

7. Joshi K C, Jain R and Arora S 1988 J. Indian Chem. Soc. 65277

8. Joshi K C, Jain R and Sharma K 1988 J. Indian Chem. Soc. 65202

9. Elagamay A G A and El-Taweel F M A A 1990 Indian J. Chem. Sect. B29 885

10. Ballini R, Bosica G, Conforti M L, Maggi R, Mazzacanni A, Righi P and Sartori G 2001 Tetrahedron 571395

11. Gao S, Tsai C H, Tseng C and Yao C F 2008 Tetrahedron 649143

12. Zhu S L, Ji S J and Zhanga Y 2007 Tetrahedron 639365

13. Wang L-M., Jiao N, Qiu J, Yu J-J, Liu J-Q, Guo F-L and Liu Y 2010 Tetrahedron 66339

14. Karimi A R and Sedaghatpour F 2010 Synthesis 101731

15. Hari G S and Lee Y R 2010 Synthesis 3453

16. Shanthi G, Subbulakshmi G and Perumal P T 2007 Tetrahedron 632057

17. Alcaide B, Almendros P, Luna A and Torres M R 2006 J. Org. Chem. 714818

18. (a) Jane J M, Hsiao Y and Armstrong J D 2006 J. Org. Chem. 71 390; (b) List B, Pojarliev P, Biller W T and Martin H J 2002 J. Am. Chem. Soc. 124827

19. (a) Rasalkar M S, Potdar M K, Mohile S S and Salunkhe M M 2005 J. Mol. Catal. A: Chem. 235 267; (b) Kotrusz P and Toma S 2006 Molecules 11 197; (c) Kotrusz P and Toma S 2006 Arkivoc 2006100

20. Ramachary D B, Chowdari N S and Barbas C F 2003 Angew. Chem. 1154365

21. (a) Yadav J S, Kumar S P, Kondaji G, Rao R S and Nagaiah K 2004 Chem. Lett. 33 1168; (b) Mabry J and Ganem B 2006 Tetrahedron Lett. 4755

22. (a) Kumar A and Maurya R A 2007 Tetrahedron 63 1946; (b) Shi C L, Shi D Q, Kim S H, Huang Z B, Ji S J and Ji M 2008 Tetrahedron 642425 